肩腕障害と腰背部障害（職業性腰痛）の健康診断を実施 した. 健診対象は, 両疾患の多発あるいは発症の危険が 考えられる職場（保育所とその他の施設, 学校給食, 清 掃，タイピング，電話交換等）で働く職員のうら, 両疾 患に関係が深いとされている自覚的訴觉が多く強いもの であった。

健診項目は，身長・体重計測，握力・背筋力・肩腕 力・立位体前屈・伏臥上体そらし・タッピング・尖光皮 虐温・痛覚・振動覚の測定, 血圧測定, 尿 - 血液検查と 問診, 視訬, 触診である.

結果：1）体格・体力等の測定值之症度 : 症度区分之 照応して測定值が並んでいるものは，タッピング，皮廂 温, 振動覚で, タッピングと振動覚とは $5 \%$ の危険率で 有意であった。

2）全身症状についての自覚的訴之と症度：症度区分 と照沁して訴充率（\%) が並んでいるものは，目がかす む，耳なりがする，どらき・息ぎれ，月経時の苦痛であ った.

3）局所症状についての自覚的訴光之症度 : 症度区分 と照応して訴党率（\%) が並んでいるものは，肩がいた い，頸がいたい，腕がいたい，手がだるい，指がひ壳 る，指の動きがわるい，下肢がいたいであった。

$$
\text { 座長のまとめ }(282 \sim 284)
$$

菰池義彦（住友病院）

282 : 調查期間は 2 週間, 保母の対照として看護学生 も使用できる.リスクファクターとして吟味は困難で, 有症状者と無症状者の比較は実施していない，周辺騒音 とは施設に隣接する道路からの交通騒音を指す，保母の 担当する子供の年龄別の検討も実施したが有意差は認め られなかった。

283 : 問診票の採点について加算法を用い重み付けは 実施していない，訴党数の分布の検定はしていないが， 座長の経験では Poisson 分布に近似すると追加した．部 位別もしくは臟器別に特異性があるように思われる．年 龄要因に関する分析では当然重視している. 本学会「頸 肩腕障害」委員会作成の問診票でも保母の健康障害の把 握がでさる，腰下肢の訴えが多いが「腰痛」委員会作成 の問診票よりも利用価值は高い, 痛覚 $3 \mathrm{~g}$ 以上, 振動覚 $5 \mathrm{~dB}$ 以上を異常とした根拠は振動障害検診成績を参考 として，これよりややゆる目を採用した。 $\mathrm{B}_{2}$ 以上の判 定を受けた率の高い職場の管理者の素質はとくに悪いと はいえない。

284 : 第 2 表の立位体前屈の測定值から各 $20 \mathrm{~cm}$ を差 し引いて見られたい。全身症状は調理員や保母が強い職 場があるが，本保育所労衝者の場合そんな例はない，保
母は頸肩腕に，清掃や調理の従業員は下肢に訴党が集中 する，症度と「うまく」並ぶ方がよいのか，覀いのか疑 問である (以上，質問者の氏名割愛).

\section{5. 学校給食調理員にみる頸肩腕障害}

田尻俊一郎, 重田博正 (大阪淀協社医研)

職業病外来や特殊健診でみる限り, 頸腕・腰痛はなお 発生しつづ，一部では桩大さえして括り，とくに給食 調理員での増加傾向をみている. その病像, 発症要因に ついての調查について述べる.

対象は82年 2 月に行ったS市学校給食調理員のう台婦 人 132 人で，これを外来，健診の資料之対比した.

現在の健康状態は，病気がち，不調が $70 \%$ 近く，装 日に残るないしは 1 日休んでも残る疲労が $47.7 \%$ にも 訴えられている，部位別症状では，外来，健診とも保母 職より高い訴公を率し，とくに手，腕，腰，下肢で著 しく, 疲労の進行とともに増加し, 痛み, しびれの項目 ではさらに抎大される。

疲学自覚症状では I dominant 型で, 作業前から高い 訴えをみせ，作業後で肩こり腰痛の訴光が顕著に増加す る.

頸腕・腰痛の訴壳をもつ者の $80 \%$ は現職についてか らの発症で，その後の発症でも $50 \%$ 余りは現職につい て増悪したといい，有訴者の 80 強が治療を必要とした。 その原因に仕事による無理 $65.9 \%$ があげられ，年齢， 家事や育児の負担がこれに続いている.

作業で負担を感じない者は男 $13.2 \%$ ，女 $1.5 \%$ と有 意差をみている，仕事でのケガ，火傷などの苂害 80〜 $53 \%$ 之日常的な危険が指摘されている。

学校給食調理作業は, 中高年の婦人にとっては夐担の 重い労働であり, 健康水準の低下, 疲労の蓄積を経て, 頸腕, 腰痛などの多発をもたらし，一層進えでゆく高跲 化のなかで，深刻な課題を投げかけていると考える。

保母職以上の保護を必要とする職種であり，健康管理 の充実, 労荻認定の促進などの諸刘策が急がれねばなら ない.

\section{6. 女子製靴学働者の頸肩腕障害——労㗢態様と臨 床像との関係について}

梅田玄勝，天野松男，中島裕而 八木邦子，竹原令宜，坂井 浩

(健和労働衛生研究所)

靴組立て作業（成型作業）以機械化が導入困難な手作 業によっている、したがってそこで発生する頸肩腕障害 には労働態様との関係において一定の特異性が認められ た. 1982年 $1 ， 6 ， 7$ 月の 3 次延べ 6 日間の調查と 1981 年 12 月以降数次にわたって要医療者の臨床観察を行っ 